\title{
Identification of sources and distribution of radiocarbon in the vicinity of La Hague nuclear reprocessing plant
}

\author{
M. Fontugne, D. Maro ${ }^{1}$, Y. Baron ${ }^{2}$, C. Hatte, D. Hebert ${ }^{1}$ and E. Douville ${ }^{1}$
}

Laboratoire des Sciences du Climat et de l'Environnement, UMR 1572 du CEAVCNRS, Domaine du CNRS, 91198 Gif-sur-Yvette cedex, France

${ }^{1}$ Institut de Protection et de Sûreté Nucléaire, Département de PRotection de l'Environnement, Service d'Études et de Recherches Radioécologiques dans les Milieux NATurels, IPSN/DPRE/SERNAT/LERFA, 50130 Cherbourg-Octeville, France

${ }^{2}$ Marine Nationale, Groupe d'Études Atomiques (GEA), BP. 34, 50115 Cherbourg Naval, France

\begin{abstract}
The terrestrial environment in the vicinity of La Hague nuclear reprocessing plant (COGEMA) is potentially influenced by two sources (atmospheric and marine) and by three ways of radionuclides transfer: 1) atmospheric fallout from old nuclear bombs experiments, 2) atmospheric fallout from gaseous throwing out from the reprocessing plant 3 ) marine aerosol and degassing (sea to land transfer) bearing radionuclides originating from liquid waste from the plant. Institute for Protection and Nuclear Safety (IPSN) has organised since 1997, with the collaboration of the Groupe d'Etudes Atomiques (GEA) de la Marine Nationale and the Laboratoire des Sciences du Climat et de l'Environnement (LSCE/CEA-CNRS), studies to identify radionuclides sources (atmospheric and marine) and to provide an evaluation of the radiocarbon around La Hague nuclear reprocessing plant and to follow the concentration evolution versus time. A sampling strategy has been established to provide a map of the distribution of radio-elements around the reprocessing plant and to identify the mode of transfers, to determine the deposition rates on soil and vegetation in order to precise the transfer model of radio-element in plants. Three experiments in terrestrial environment with sampling of a bioindicator like furze has done in 1997, 1998 and 1999. In 2000, during TE-SEA cruise with the Research Vessel (RV) "Cotes de la Manche", the specific objective was to determine if there was ${ }^{14} \mathrm{C}$ transfer as $\mathrm{CO}_{2}$ between sea to land.
\end{abstract}

\section{INTRODUCTION}

La Hague nuclear reprocessing plant (COGEMA) is located in the north west of Cotentin peninsula near Cherbourg (France). This nuclear plant release radionuclides in atmosphere and in the English Channel. The aim of this study is to present the distribution of radiocarbon in the vicinity of La Hague reprocessing plant, but also at sea along the western coast of Nord Cotentin, and to determine if there is ${ }^{14} \mathrm{C}$ transfer as $\mathrm{CO}_{2}$ between sea to land.

\section{MATERIALS AND METHODS}

Radiocarbon is released to the environment as $\mathrm{CO}_{2}$ [1] through a 100 metre high chimney and as liquid waste few kilometres off sea shore, west of the reprocessing plant. The carbon dioxide is assimilated by plants through photosynthetic processes. Consequently, the ${ }^{14} \mathrm{C}$ activity of vegetation constitute an integrated record of COGEMA La Hague emissions, during the vegetative period (spring to fall). We collect [2] during three years (1997-1999) the spring growth of furze of twenty stations (figure 1). The radiocarbon activity was measured at Laboratoire de Sciences du Climat et de l'Environnement (LSCE) at Gif/Yvette for years 1997 and 1998 and at University of Georgia (USA) for 1999 samples. The samples were prepared using classical methods [3] and was measured by beta counting in $\mathrm{CO}_{2}$ proportional gas counters at LSCE and by benzene liquid scintillation at Georgia University. 


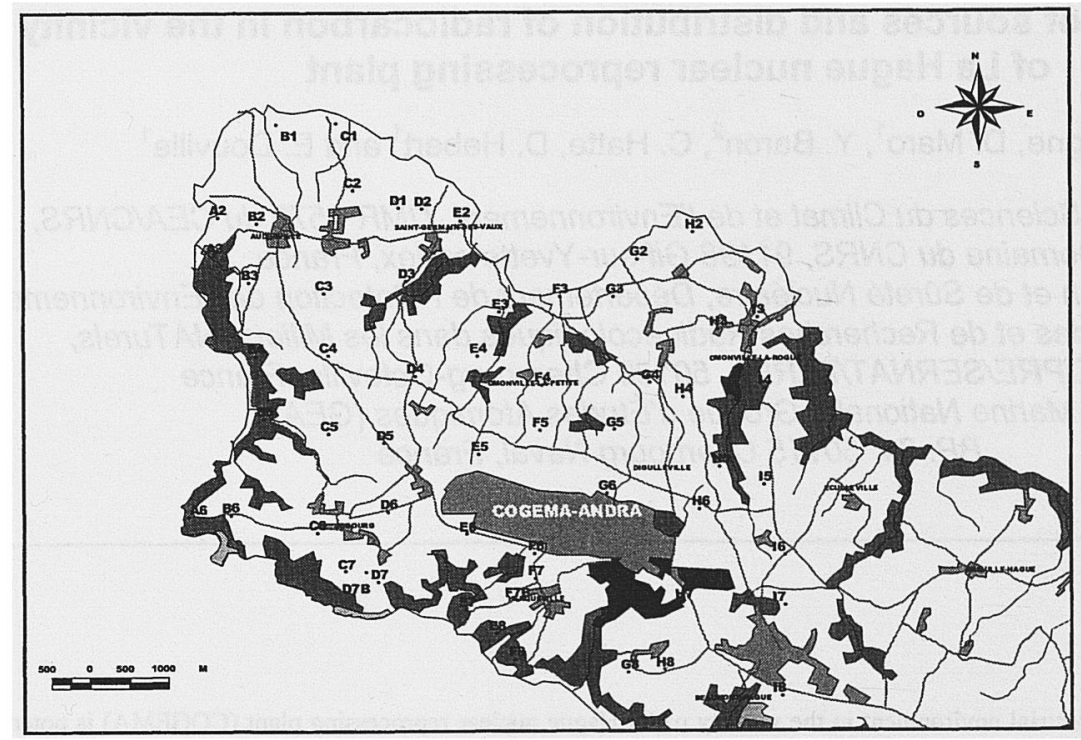

(a)

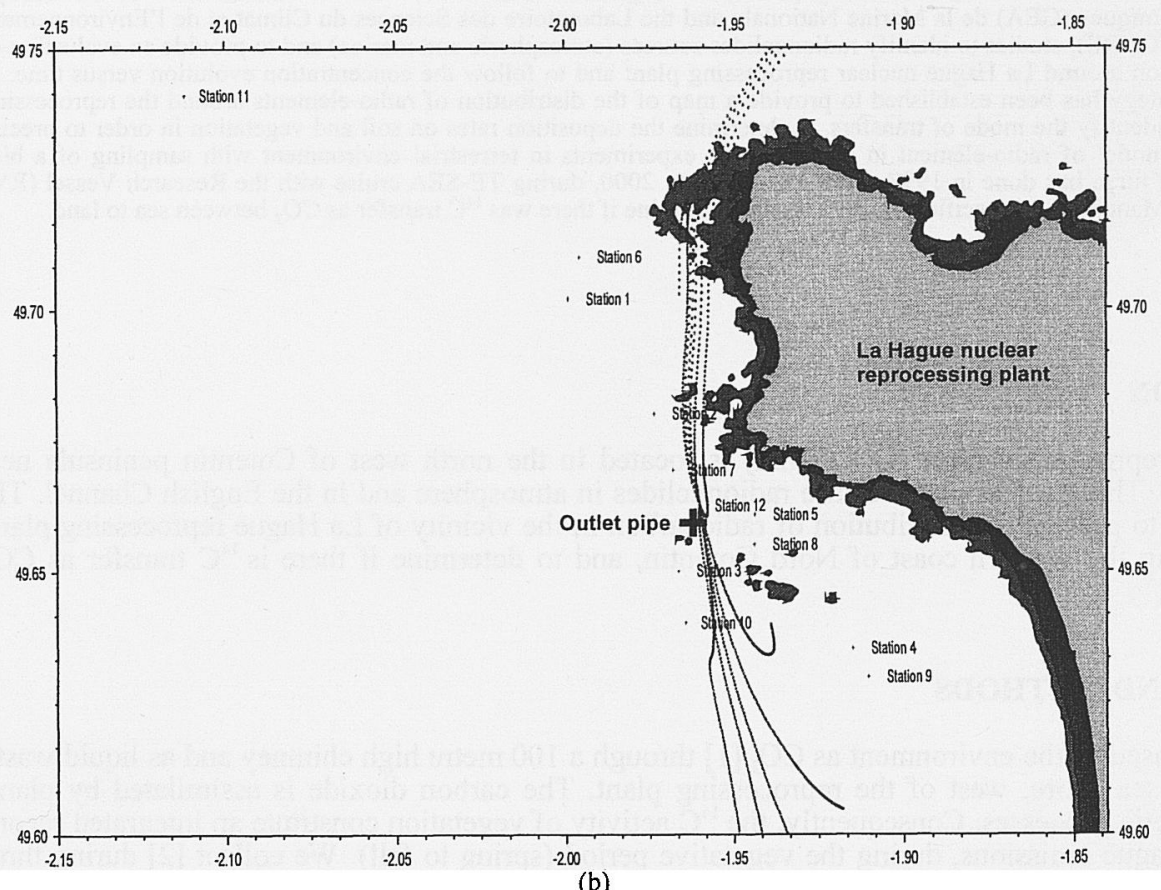

Figure 1 : Samples of furze (20 samples for ${ }^{14} \mathrm{C}$ analysis) collected around La Hague nuclear reprocessing plant (a) and samples (12 sampling stations) of water, air and seston collected during TE-SEA cruise (b) 
At sea, air, water and seston samples were collected in June 2000 during the TESEA cruise on board of RV "Côtes de la Manche" and prepared for analysis at LSCE. Twelve water samples were collected in glass bottle and poisoned with mercury chloride. At laboratory, total $\mathrm{CO}_{2}$ was extracted from seawater following the procedure described by Bard et al. [4] and Leboucher [5]. At the same locations, $\mathrm{CO}_{2}$ in few litres of air was trapped by bubbling air in sodium hydroxide. Collection of air samples was done at $1 \mathrm{~m}$ above sea level.

At laboratory, barium hydroxide was added in sodium hydroxide solution to get a precipitate of barium carbonate. This carbonate was then rinsed with degassed distilled water and dried at $50^{\circ} \mathrm{C}$ before reaction with ortho-phosphoric acid under vacuum to get $\mathrm{CO}_{2}$. Water used to prepare solution were previously degassed. Precipitation, filtration of precipitate and rinse were performed under controlled nitrogen atmosphere. The blank was determined following this procedure on the same solution used for sampling.

Seston (suspended matter) was collected used a seston net $(20 \mu \mathrm{m})$ and dried at $50^{\circ} \mathrm{C}$ before analyses. All TE-SEA cruise samples were analysed for ${ }^{14} \mathrm{C}$ activity using accelerator mass spectrometry with Gif AMS facilities. Results are expressed in percent modern (PMc) [6] or in Becquerel. $\mathrm{kg}^{-1} \mathrm{C},(100 \% \mathrm{PMc}=$ is equivalent to $226 \mathrm{~Bq} \cdot \mathrm{kg}^{-1} \mathrm{C}$ ). The standard deviation varies between 0,5 and $2 \%$ for Gif measurements and between 1,3 and $4,4 \%$ for Georgia University.

$\mathrm{pCO} 2$ measurements in water were determined from $\mathrm{pH}$ and alkalinity according to Dickson methodology [7] [8].

\section{RESULTS AND DISCUSSION}

\section{$3.1{ }^{14} \mathrm{C}$ activity in furze}

Results are reported in Figure 2.

${ }^{14} \mathrm{C}$ activity varies between 250,5 and $587,1 \mathrm{~Bq} \cdot \mathrm{kg}^{-4} \mathrm{C}$. Reference samples were collected in Brittany $300 \mathrm{~km}$ south-west from La Hague gave value between 252,6 and 254,3 in good agreement with ${ }^{14} \mathrm{C}$ activity in air and plants growing outside areas contaminated by industrial ${ }^{14} \mathrm{C}$. Samples from La Hague clearly record the influence of the reprocessing plant. The ${ }^{14} \mathrm{C}$ distribution are similar for the three considered years and is clearly depending on the wind direction mainly a SW and ENE axe during vegetative period.

\section{$3.2{ }^{14} \mathrm{C}$ activity in sea water and seston}

Results are reported in table 1.

A reference values $\mathrm{PMc}=110\left(248 \mathrm{~Bq} \cdot \mathrm{kg}^{-1} \mathrm{C}\right)$ for modern surface waters was measured in Brittany off Brest city. The ${ }^{14} \mathrm{C}$ activities of $\sum \mathrm{CO}_{2}$ in seawater vary between $342.2 \mathrm{~Bq} \cdot \mathrm{kg}^{-1}$ at station 11 in the north-west of the studied area to $580.8 \mathrm{~Bq} \cdot \mathrm{kg}^{-1} \mathrm{C}$ near the mouth of the pipe of La Hague nuclear reprocessing plant. The values (except Station 11) range between 479.6 to $580.8 \mathrm{~Bq} \cdot \mathrm{kg}^{-1} \mathrm{C}$ decreasing from south to north recording clearly the plume and the dilution of wastes.

Only six samples of seston were collected at stations 11 and 3 to 7 . The ${ }^{14} \mathrm{C}$ activity is significantly lower than that of $\Sigma \mathrm{CO} 2$ in seawater measured at the same location. The lowest value is recorded at the mouth of the pipe (station 3) and the highest at $3-4 \mathrm{~km}$ north and east of the mouth. The first explanation for these differences between seawater and seston activity relies on the large mixing of water resulting of the strength of tidal current in this region. A part of the seston community could originate from areas which are not affected by releases.

As a second explanation, ${ }^{14} \mathrm{C}$ is released as bicarbonate in alkaline solution. This solution is diluted and re-equilibration between dissolved $\mathrm{CO}_{2}$, bicarbonate and carbonate progressively takes place. As only dissolved $\mathrm{CO}_{2}$ representing less than $5 \%$ of total $\mathrm{CO}_{2}$ can be used during photosynthetic processes these results suggest that re-equilibration is not complete. 


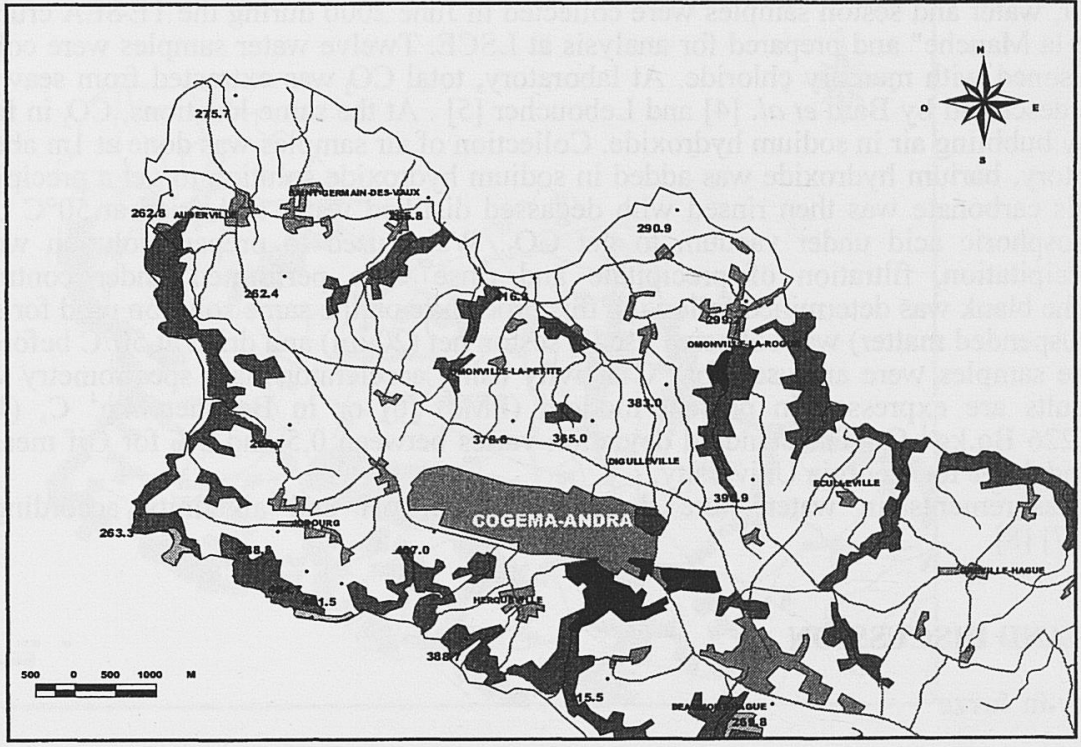

(a) Activities (Bq.kg- ${ }^{-1}$ ) in samples collected in 1997

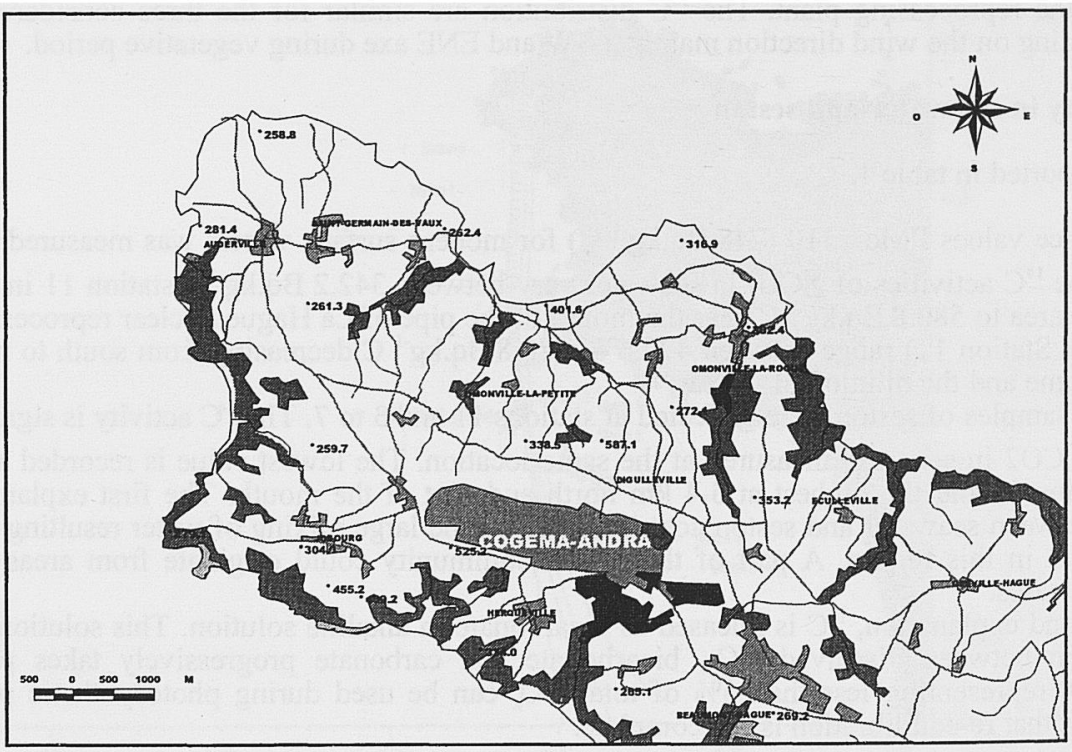

(b) Activities (Bq. $\left.\mathrm{kg}^{-1} \mathrm{C}\right)$ in samples collected in 1998 


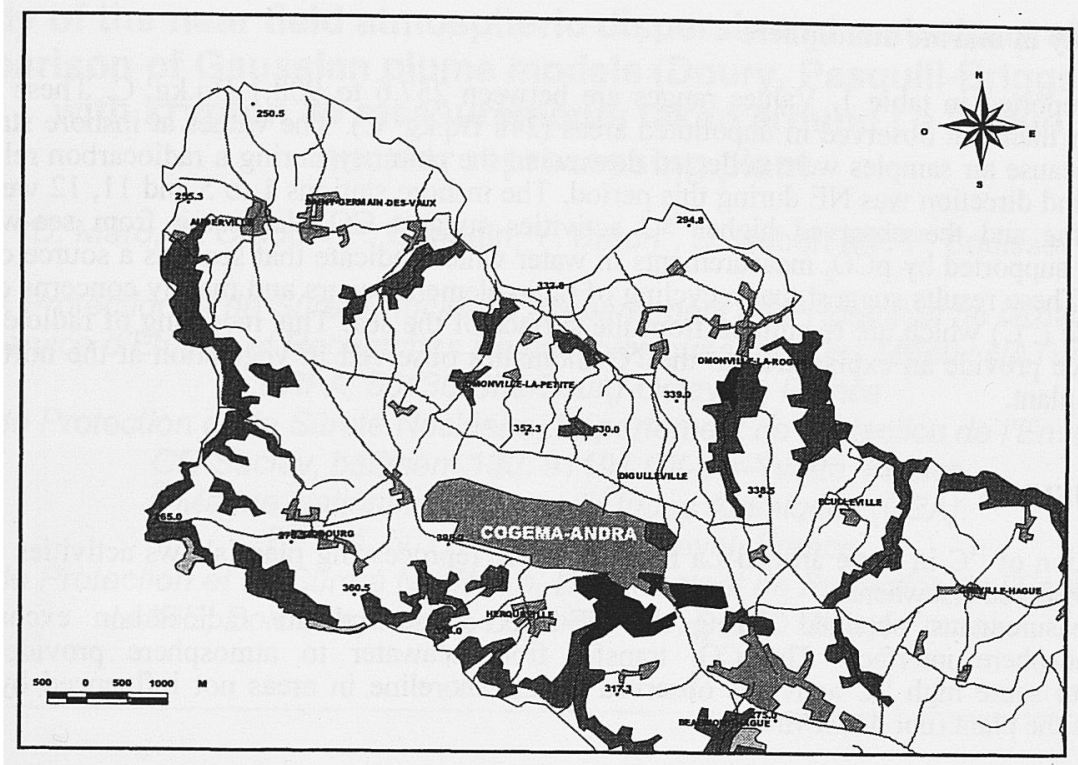

(c) Activities (Bq.kg-' C) in samples collected in 1999

Figure 2: ${ }^{14} \mathrm{C}$ activities in furze in 1997 (a), 1998 (b) and 1999 (c)

Table 1: ${ }^{14} \mathrm{C}$ activities in samples during TE-SEA cruise (Bq. $\left.\mathrm{kg}^{-1} \mathrm{C}\right)$

\begin{tabular}{ccccccccc}
\hline Station & Sea Water & \multicolumn{3}{c}{ Seston } & \multicolumn{3}{c}{ Air } \\
\hline 1 & 480.7 & \pm 2.9 & & & & 268.5 & \pm & 3.2 \\
\hline 2 & 506.0 & \pm 3.4 & & & & 279.1 & \pm & 3.8 \\
\hline 3 & 527.0 & \pm 3.2 & 236.8 & \pm & 1.8 & 257.6 & \pm & 3.2 \\
\hline 4 & 562.3 & \pm 3.4 & 350.1 & \pm & 2.5 & 269.8 & \pm & 3.4 \\
\hline 5 & 520.3 & \pm 3.4 & 394.1 & \pm & 2.7 & 259.4 & \pm & 2.9 \\
\hline 6 & 479.6 & \pm 3.2 & 259.2 & \pm & 1.8 & 428.9 & \pm & 2.5 \\
\hline 7 & 539.7 & \pm 3.4 & 253.3 & \pm & 1.8 & 468.7 & \pm & 2.7 \\
\hline 8 & 559.6 & \pm 3.6 & & & & 435.1 & \pm & 2.7 \\
\hline 9 & 557.8 & \pm 3.6 & & & & 908.1 & \pm & 3.2 \\
\hline 10 & 506.2 & \pm 3.2 & & & & 426.0 & \pm & 2.7 \\
\hline 11 & 342.2 & \pm 2.5 & 268.5 & \pm & 2.0 & 271.2 & \pm & 3.4 \\
\hline 12 & 580.8 & \pm 3.4 & & & & 292.2 & \pm & 4.1 \\
\hline 56
\end{tabular}




\section{$3.3{ }^{14} \mathrm{C}$ activity in marine atmosphere}

Results are reported in table 1 . Values ranges are between 257.6 to $908.1 \mathrm{~Bq} \cdot \mathrm{kg}^{-1} \mathrm{C}$. These activities are clearly higher than that observed in unpolluted areas $\left(248 \mathrm{~Bq} \cdot \mathrm{kg}^{-1} \mathrm{C}\right)$. The values at inshore stations 6 to 10 are higher because air samples were collected downwind the chimney during a radiocarbon release from the plant. The wind direction was NE during this period. The inshore stations 1 to 5 and 11,12 were not located into the plume and the observed higher ${ }^{14} \mathrm{C}$ activities suggest $\mathrm{CO}_{2}$ degassing from sea-water. Such a hypothesis is supported by $\mathrm{pCO}_{2}$ measurements in water which indicate that sea was a source of $\mathrm{CO}_{2}$ for the atmosphere. These results suggest that recycling of radio-element occurs and mainly concerns elements with gaseous phase $\left({ }^{14} \mathrm{C}\right)$ which are re-emitted from the surface of the sea. This recycling of radio-elements from the sea-surface provide an explanation to the ${ }^{14} \mathrm{C}$ anomalies observed in vegetation at the north west of the reprocessing plant.

\section{CONCLUSIONS}

The distribution of ${ }^{14} \mathrm{C}$ in furze around La Hague nuclear reprocessing plant shows activities once to twice higher that observed elsewhere.

The measurements obtained during the TE-SEA cruise indicate radiocarbon exchanges at the seawater/atmosphere interface. The $\mathrm{CO}_{2}$ transfer from seawater to atmosphere provides a possible explanation to some high ${ }^{14} \mathrm{C}$ activities observed on the shoreline in areas not influenced by atmospheric releases from the plant (not downwind).

\section{Acknowledgments}

We thank the captain and the Crew of the RV "Côtes de la Manche" and M. Arnold and M. Paterne for Gif AMS facilities.

\section{References}

[1]Goumondy J.P., Evaluation de l'incertitude concernant les rejets radioactifs gazeux des usines de COGEMA/HAGUE (Tritium, C14, Kr85), DES/DIR 2001-311, (Ed. IPSN) (2001) pp 4.

[2]. Maro D., Baron Y., Fontugne M., Hadji K., Hatte C., Germain P., Hebert D., Solier L., Evolution de la radioactivité artificielle dans un bioindicateur, l'ajonc d'Europe, autour de l'usine de retraitement des combustibles irradiés de La Hague (bilan de trois campagnes de mesures réalisées entre 1997 et 1999), Rapport DPRE/SERNAT/0037 (Ed. IPSN) (2000) pp 39.

[3]. Délibrias G., Le carbone 14- Méthodes de datation par les phénomènes nucléaires naturels: application. Eds: Roth E., Poty B., Coll.CEA, Masson (Paris) (1985) pp 421458.

[4]. Bard E., Arnold M., Ostlund H. G., Maurice P., Monfray P., Duplessy JE., (1988) Earth Planet. Sci. Lett., 87 (1988) 379-389.

[5]. Leboucher V., (1999). Carbone 14 et tritium thermonucléaire traceur de la circulation des masse d'eaux et de la pénétration du $\mathrm{CO}_{2}$ anthropique dans l'océan Indien. Thèse Université Paris VI, (1999) pp202.

[6]. Stuiver M., Polach H., Radiocarbon, 19 (1997) 355-363.

[7]. Dickson A.G., The development of the alkalinity concept in marine chemistry. Marine chemistry. 40 (1992). 4963.

[8]. Dickson A.G., The measurement of sea water pH. Marine chemistry. 44, (1993). 131142. 